\title{
KIDNEY SPHAEROSPOROSIS WITH EXTRASPOROGONIC STAGES IN THE BLOOD IN BARYANCISTRUS SP. (LORICARIDAE) FROM AMAZONIAN BRAZIL
}

\author{
PAPERNA I.* \& DI CAVE D.**
}

\begin{abstract}
Summary :
Examined fish of the genus Baryancistrus (Loricaridae) from Rio Xingu in central amazonian Brazil were found infected with extrasporogonic stages of Sphaerospora sp. (Myxosporea) in the blood and sporogonic stages in the glomeruli with the resulting escape of the sporogony products into the renal tubules, apparently when the mesangial tissue in the Bowman's capsule collapsed. Spores were seen evacuating via the urinary tubules. Blood stages were initially $2.1 \times 2.8$ to $2.8 \times 2.8 \mu \mathrm{m}$ in size, and when fully differentiated reached $5.6 \times 5.6-5.6 \times 7.0 \mu \mathrm{m}$; in blood smears they were $11.2 \times 8.4$ to $14 \times 8.4 \mu \mathrm{m}$.

Bisporoblasts in the glomerular taft were $9.8 \times 7.0 \mu \mathrm{m}$, premature spores were $5.6 \times 4.2-5.6 \mu \mathrm{m}$.
\end{abstract}

KEY WORDS : sphaerosporosis, Myxosporea, Baryancistrus, Loricaridae, Brazil, extrasporogony, blood, sporogony, glomerulus

\section{INTRODUCTION}

T The fish host, an unidentified species of Baryancistrus (a "large white-spotted gold nugget" plecostomid) (Loricaridae), was collected in Rio Xingu, in the central amazonian region; only one of the seven examined fishes was found infected. No other species of Sphaerospora (Phyllum Myxosporea) have been thus far described from Neotropical fish. The presently reported Sphaerospora is most likely an undescribed species.

\section{MATERIALS AND METHODS}

$\mathrm{P}$ repared blood films and touch imprints of liver, spleen and kidneys were air-dried, fixed in methyl alcohol and stained in Giemsa diluted in pH 7.4 phosphate buffer. For histology, small (2-4 $\left.\mathrm{mm}^{3}\right)$

\footnotetext{
* Department of Animal Sciences, Faculty of Agriculture of the Hebrew University of Jerusalem, Rehovot 76100 , Israel.

** Cattedra di Parassitologia, Dipartimento di Sanitá pubblica e Biologia Cellulare, Universita degli Studi di Roma "Tor Vergata". Via Tor Vergata 135, 00133, Rome, Italy.

Correspondence: Ilan Paperna.

Tel.: 97289489945 - Fax: 97289465763.

E-mail: paperna@agri.huji.ac.il
}

Résumé : SPHAEROSPOROSE RÉNALE AVEC STADE D'EXTRASPOROGONIE AU NIVEAU SANGUIN CHEZ BARYANCISTRUS SP. (LORICARIDAE) DE L'AMAZONIE AU BRÉSIL

Des poissons du genre Baryancistrus (Loricaridea) du Rio Xingu de l'Amazonie centrale au Brésil ont été trouvés infectés par Sphaerospora sp. (Myxospora) au stade d'extrasporogonie dans le sang et de sporogonie au niveau du glomérule rénal avec libération dans le tubule. L'élimination de spores par le tubule rénal a été observée. Les tailles des stades sanguins initialement de $2,1 \times 2,8$ à $2,8 \times 2,8$ um ont atteint à un stade plus différencié 5,6 × 5,6 à 5,6 $\times 7,0 \mu \mathrm{m}$; en goutte épaisse elles étaient de 11,2 ×8,4 à $14 \times 8,4 \mu \mathrm{m}$; celles des bisporoblastes dans les glomérules étaient de 9,8 $87,0 \mu \mathrm{m}$ et des spores prématures de 5,6 4 4,2-5,6 $\mathrm{um}$.

MOTS CLÉS : sphaerosporose, Myxospora, Baryancistrus, Loricaridae, Brésil, extrasporogonie, sang, sporogonie, glomérule.

segments of these tissues were fixed in $10 \%$ neutralbuffered formalin and embedded in glycol methacrylate medium (GMA, Agar Scientific Ltd., U.K.). Sections (2.0-3.0 $\mu \mathrm{m})$ were cut in a Sorval JB4 glass-knife microtome and stained with Meyer's haemalum eosin.

\section{RESULTS AND DISCUSSION}

F ree extrasporogenic stages were observed in the blood, they were especially numerous in the liver lacunas. (Figs. 1a-f, 2, 3). Initial stages (or daughter units of divided polynuclear stages), $2.1 \times 2.8$ to $2.8 \times 2.8 \mu \mathrm{m}$ in size, contained one primary and one secondary cell (Fig. 1a). Secondary cells, $4.2 \times 4.9$ to $4.9 \times 5.6 \mu \mathrm{m}$, prior to division contained a vesiculate nucleus with a prominent nucleolus (Fig. 1b). A large extrasporogonic stage, $5.6 \times 5.6$ to $5.6 \times 7.0 \mu \mathrm{m}$, with a superficial primary cell contained either three to six secondary cells, each with a tertiary cell, or a single secondary cell with three to six tertiary cells, each revealing the nucleus of the quaternary cell (Fig. 1c-e). Some fully differentiated cells in Giemsa-stained blood films reached $11.2 \times 8.4$ to $14 \times 8.4 \mu \mathrm{m}$ (Fig. 1f). In some of these cells, the primary cell appeared to separate gradually from the remaining cell, or disappear altogether (Fig. 1e). Extrasporogenic stages settled (or 

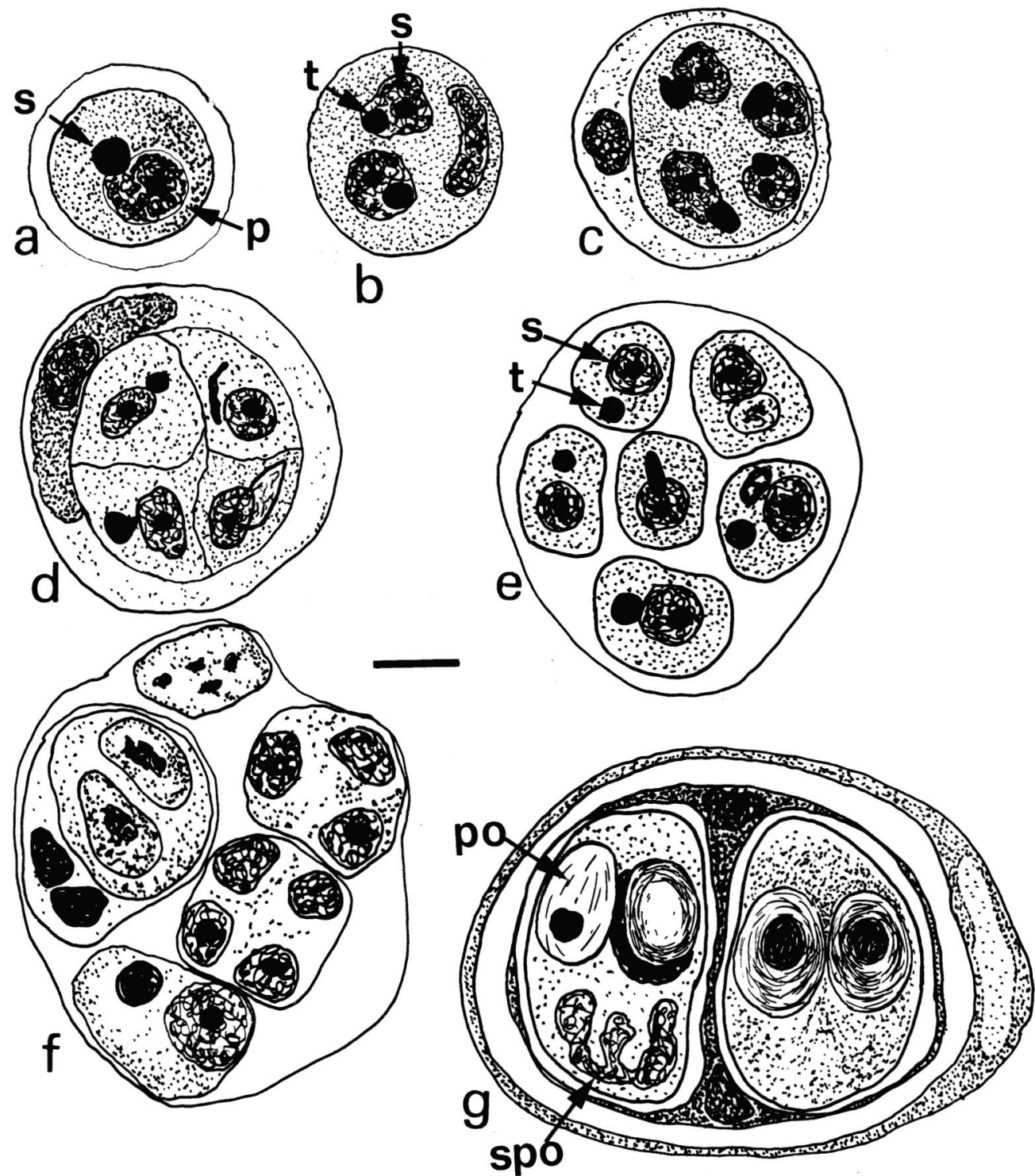

Fig. 1. - Developmental stages of Sphaerospora sp. from Baryancistrus sp., drawn from a Giemsa stained kidney touch preparation. a. Iinitial stage with one primary (p) and one secondary cell nucleus (s); b. with one primary elongate and two secondary cell nuclei (s), each enclosing a tertiary cell nucleus (t); c. Differentiation of the secondary cell; d. with the secondary cell in division; e. with division completed (s, secondary and $\mathrm{t}$, tertiary cell nuclei); f. further division of secondary cell progeny; g. bisporoblast from the glomerulus, showing sporoplasm (spo) and polar cells (po). (Scale $=1 \mu \mathrm{m})$. 

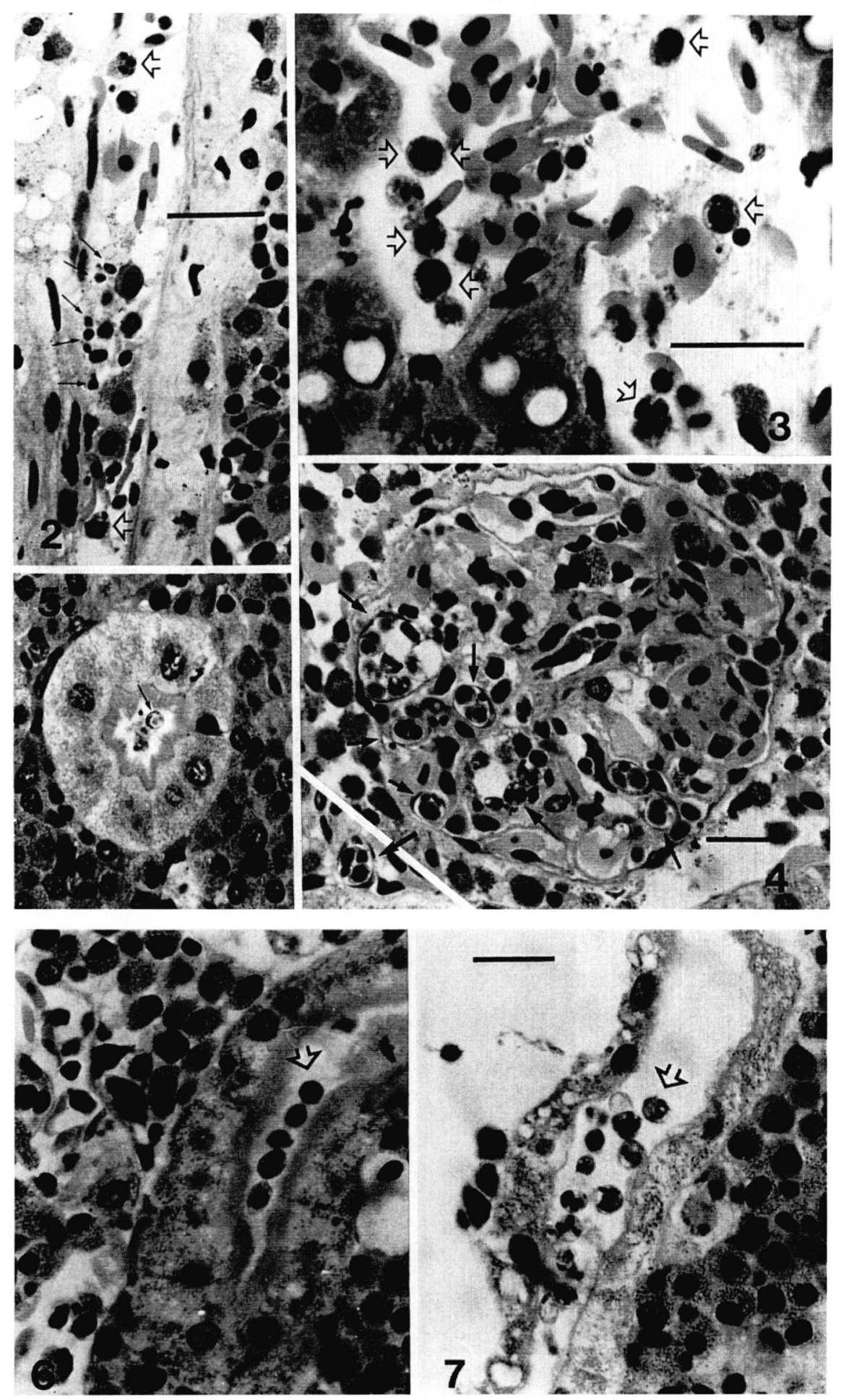

Figs. 2-5. - 2. Extrasporogonic blood stages of Sphaerospora sp.: primary, secondary (fine arrows) and tertiary cells (open arrows) in an hepatic blood vessel. 3. Enlarged view of a hepatic lacuna containing many fully developed extrasporogonic stages (open arrows). 4. Sporoblastic stages within the glomerulus (arrows); annex-bold arrow: sporoblast in the periphery of a renal tubule. 5. Spores in the renal tubule lumen.

Figs. 6-7. - Sporoblastic stages and spores in the renal tubule (open arrows) (Scales $=20 \mu \mathrm{m}$, Figs. 4 \& 5 and 6 \& 7 same magnification). 
were trapped) in the glomerulus and proceeded to the sporoblastic stage. Developing bisporoblasts occurred singly, reaching $9.8 \times 7.0 \mu \mathrm{m}$ in dimension (Fig. 1g), or several within a plasmodium, reaching a size of 19.6 $\times 16.8 \mu \mathrm{m}$ (Fig. 4); a few sporoblasts were also seen adjacent to the base of a renal tubule (Fig. 5). Sporoblast and $5.6 \times 4.2-5.6 \mu \mathrm{m}$ differentiated spores occurred in the glomerulus as well as in the tubular lumen (Figs. 6-8). The sporogonous development appears to bring about the collapse of the glomerular-mesangial tissue in the bowman capsule with the resulting escape of the sporogony products into the renal tubules, allowing the spores to be liberated through the excretory system. The infection observed in the fish yielded only a few ripe spores. Unprocessed spores were not available for examination as the infection was detected only after processing for histology, thus leaving this Sphaerospora's specific identity unresolved.

Extrasporogonic stages in the blood are part of the life history of several species of Sphaerospora infecting cyprinid-fish hosts in Europe (Lom et al., 1983, 1985; Baska \& Molnar, 1988; Molnar, 1988); some are very similar to the presently observed developmental stages in the blood, others, including Sphaerospora renicola from the common carp, differ by their typical elongated secondary cells. All species from cyprinid fishes, however, sporulate in the kidney tubuli. Sporoblastic development in the glomeruli occurs in species of Sphaerospora and related genera (Polysporoplasma) infecting marine fish (Sitja-Bobadilla \& Alvarez-Pelliteiro, 1995).

\section{REFERENCES}

BASKa F. \& MOLnar K. Blood stages of Sphaerospora spp. (Myxosporea) in cyprinid fishes. Diseases of Aquatic Organisms, 1988, 5, 23-28.

lom J., Dykova I. \& Pavlaskova M. "Unidentified" mobile protozoan from the blood of carp and some unsolved problems of Myxosporean life cycles. Journal of Protozoology, 1983, 30, 497-508.

lom J., Pavlaskova M. \& Dykova I. Note on kidney-infecting species of the genus Sphaerospora Thelohan (Myxosporea), including a new species $S$. gobionis sp. nov., and on myxosporean life cycle stages in the blood of some freshwater fish. Journal of Fish Diseases, 1985, 8, 221-232.

MOLNAR K. Evidence that C-blood protozoa of the common carp are stages of Sphaerospora renicola Dykova \& Lom 1982. Bulletin of the European Association of Fish Patholgists, 1988, 4, 14-15.

Sitja-Bobadilla A. \& Alvarez-Pellitero P. Light and electron microscopic description of Polysporoplasma n.g. (Myxosporea: Bivalvulida), Polysporoplasma sparis n. sp. from Sparus aurata (L.), and Polysporoplasma mugilis n. sp. from Liza aurata L. European Journal of Protistology, 1995, 31, 77-89.

Reçu le 17 juillet 2000

Accepté le 22 septembre 2000 